\title{
Nutrition Detection Status Of Children Based On The Provision Of Breastmilk And Supplement
}

\author{
Desilestia Dwi Salmarini ${ }^{1}$ \\ ${ }^{1}$ Academy of Midwifery Sari Mulia Banjarmasin, Indonesia \\ *desilestiadwisalmarini@gmail.com \\ Annisa Citra $S^{1}$ \\ ${ }^{1}$ Academy of Midwifery Sari Mulia Banjarmasin, Indonesia \\ annisacitra83@gmail.com
}

\begin{abstract}
Objective: The aim of this study to detect nutrition status of a child through Pattern of breastfeeding based on schedule, type, and frequency in working area of Kelayan Dalam Public Health Center Banjarmasin.

Technology or Methods: This research used analytic survey with cross sectional design. The population in this study were all mothers who had children aged 6-24 amounting to about 33 mothers in the working area of Kelayan Dalam Public Health Center. Sampling technique was using total population.

Results: The results of the analysis revealed that the nutritional status of under-five children can be detected through maternal breastfeeding ( $\mathrm{p}$-value $=0,000)$, where the frequent feeding ( $\mathrm{p}$-value $=$ 0,000 ) is the most dominant factor in the nutritional status of children under five.

Conclusion: Breastfeeding complimentary patterns may affect the nutritional status of children under five. The frequency of feeding is a dominant factor that can determine the nutritional status of children while for the type and schedule of feeding is not a factor to the nutritional status of children.
\end{abstract}

Keywords: Breastfeeding, Breastfeeding complimentary, Maternal, Nutritional status 


\section{INTRODUCTION}

The World Health Organization (WHO, 2011) estimates that $54 \%$ of child deaths are caused by malnutrition [1]. In Indonesia, it is currently recorded that $4.5 \%$ of the 22 million toddlers or 900 thousand children under five suffer from malnutrition or malnutrition and result in child mortality up to $80 \%$ [2].

Breastfeeding Foods (MP-ASI) are foods or beverages containing nutrients given to infants or children older than 6 months to meet nutritional needs other than breast milk. This is because breast milk is only able to meet two-thirds of the needs of infants at 6-9 months of age, and at the age of 9-12 months meet half of the baby's needs [3]. At the age of 0-6 months, the baby does not need food or drinks other than breast milk. This means that babies only get the mother's milk without any additional fluids, either formula, honey, tea water. Babies are also not given other solid foods such as bananas, rice pulp, porridge, milk, biscuits, rice teams and others. MP-ASI should begin to be given when the baby no longer gets enough energy and nutrients from breast milk alone [4]. Nutrition disorders in infants and under-fives are generally due to poor quality and pattern of feeding. The pattern of giving the MP-ASI is divided into several classifications such as type, frequency, and schedule. Supplementary feeding should vary, from the form of a slurry to a thick slurry, juice, fresh fruit, crushed food, soft foods and solid foods [5].

In Indonesia, the number of malnutrition cases in 2012 was 42,702 cases. It has decreased by approximately $14 \%$, but in recent years the decline is very gentle [6]. Based on monitoring data of nutritional status of children under five years in Indonesia in 2015 found the Nutritional Status of Toddler according to Index of body weight per age (BB / U) $79,7 \%$ good nutrition, $14,9 \%$ less nutrition, $3,8 \%$ malnutrition and $1.5 \%$ more nutrition. For the nutritional status of children under five weight index per body height (BB / TB), the results obtained $82.7 \%$ normal, $5.3 \%$ fat, and $3.7 \%$ very thin.

According to WHO (2011) assessed fewer malnutrition cases in Indonesia is still high ie 5 million children under five or $27.5 \%$ have less nutrition. The annual report of South Kalimantan Provincial Health Office shows that the number of under-fives suffering from malnutrition is less than 4,914 people from 45,189 people. According to the Health Service of Banjarmasin city, it shows that the nutritional status of children under five in the city of Banjarmasin according to the weighted index per age (BB / U) of 2014 that suffered from malnutrition $1.14 \%$, less 
nutrition $5.89 \%, 91.11 \%$ more nutrition $1.89 \%$. Whereas in 2015 the nutritional status of children under five years old weight $(\mathrm{BB} / \mathrm{U})$ of under-five who suffered malnutrition $1.74 \%$, less nutrition $8.26 \%$, good nutrition $86.46 \%$ and more nutrition $3.51 \%$ [7].

Based on data from the Banjarmasin City Health Office in 2015, 3 percent of the largest health centers with malnutrition in toddlers are Kelayan Dalam Public Health Center 6.20\%, Puskesmas Pemurus Baru $4.65 \%$ and Teluk Tiram Puskesmas $4.59 \%$. Based on data obtained from health center Kelayan Dalam Banjarmasin, in the year 2014 weight calculation according to age (BB / U) have more nutrition 17,00\%, good nutrition $56,82 \%$, less nutrition $10,13 \%$ and malnutrition $11,98 \%$. Whereas in 2015 with the target number of under-five children under five years old was found weight calculation according to age $(\mathrm{BB} / \mathrm{U})$ with the result of nutrient over $7,60 \%$, good nutrition $72,16 \%$, less nutrition $14,14 \%$ and less nutrition $6,20 \%$.

Based on the above description of the researcher interested in conducting research entitled "Detection of Under-five Nutritional Status Based on Provision of MP-ASI". The purpose of this research is to Analyze the Relation Pattern of Giving of Breastfeeding with nutritional status of infants aged 6-24 months in working area of Kelayan Dalam public health center "

\section{RESEARCH METHODS}

This research type is analytic survey research and use cross sectional approach.

The population of this study is all mothers who have children aged 6-24 months who run exclusively breastfed amounted to 33 people in the working area of Puskesmas Kelayan Dalam.

Sampling technique used is total sampling that is as much as 33 samples used as respondents by using a checklist tool.

\section{RESULTS}

Frequency distribution of Nutrition Status of Toddler Aged 6-24 Month in the Working Area of Kelayan In Banjarmasin Public Health Center in this research is as follows:

Tabel 1. Frequency Distribution Based on Nutrition Status

\begin{tabular}{lcc}
\hline Nutrition Status & $\mathrm{N}$ & $\%$ \\
\hline Bad nourished & 2 & $6 \%$ \\
Inadequately & 6 & $19 \%$ \\
nourished & 25 & $75 \%$ \\
Well nourished & 0 & $0 \%$ \\
Too nourished & 33 & $100 \%$ \\
\hline \multicolumn{1}{c}{ Total } &
\end{tabular}

Based on Table 1 of nutrition status, from 33 people found that the nutritional status of children aged 6-24 months most with good nutrition status that is as many as 25 people $(75 \%)$, but still found 
toddlers with malnutrition status of 2 people $(6 \%)$.
Table 4. Provision Pattern of Supplement and Breastmilk based on Frequency

Provision Pattern of Supplement and N $\%$
Breastmilk (Frequency)

Table 2. Frequency Distribution of nutrition status based

\begin{tabular}{|c|c|c|c|}
\hline Gender & Nutrition Classification & $\mathrm{N}$ & $\%$ \\
\hline \multirow[t]{4}{*}{ Males } & Bad nourished & 1 & $3 \%$ \\
\hline & Inadequately nourished & 4 & $12 \%$ \\
\hline & Well nourished & 8 & $25 \%$ \\
\hline & Too nourished & 0 & $0 \%$ \\
\hline \multirow[t]{4}{*}{ Females } & Bad nourished & 1 & $3 \%$ \\
\hline & Inadequately nourished & 2 & $6 \%$ \\
\hline & Well nourished & 17 & $51 \%$ \\
\hline & Too nourished & 0 & $0 \%$ \\
\hline Total & & 33 & $100 \%$ \\
\hline
\end{tabular}

Table 2 shows nutritional status by gender. Male gender of 14 children under five years old 6-24 months with good nutrition status that is as much as 8 people (25\%) circulate sex of woman from 19 children of age 6-24 month with good nutrition status that is 17 respondents (51 $\%)$.

Table 3. Patterns of Supplement Provision and Breastmilk Based on the type of food

\begin{tabular}{lcc}
\hline Patterns & $\mathrm{N}$ & $\%$ \\
\hline Proper & 23 & 70 \\
Improper & 10 & 30 \\
\hline Total & 33 & 100
\end{tabular}

Table 3 shows the distribution of the pattern of provision of supplement and breast milk based on the type. As many as 2323 people (70\%) got proper type, but 10 people $(10 \%)$ did not get the proper one.

\begin{tabular}{lll}
\hline Proper & 17 & 51
\end{tabular}

Improper $\quad 16 \quad 49$

Total $33 \quad 100$

Source: Primary Data

Table 4 shows the distribution of milk based on the frequency. As many as 17 respondents $(51 \%)$ are proper, but 16 respondents $(49 \%)$ are not proper.

Table 5. Schedule-based Pattern of Provision of Supplement and

\begin{tabular}{lcc}
\hline Provision pattern of supplement & $\mathrm{N}$ & $\%$ \\
and breast milk (schedule)) & & \\
\hline Proper & 22 & 67 \\
Improper & 11 & 33 \\
\hline Total & 33 & 100
\end{tabular}

Table 5 shows Pattern Distribution of Provision of supplement and breast milk based on the schedule. As many as 22 respondents $(67 \%)$ are proper, but 11 respondents (33\%) are not proper.

Table 6. Provision Pattern of Supplement and Breastmilk

\begin{tabular}{lcc}
\hline $\begin{array}{l}\text { Supplement Pattern of } \\
\text { Supplement and Breastmilk }\end{array}$ & $\mathrm{N}$ & $\%$ \\
\hline Proper & 16 & 49 \\
Improper & 17 & 51 \\
\hline Total & 33 & 100 \\
\hline
\end{tabular}

Table 6 shows the distribution of Provision Pattern of supplement and breast milk. As many as 16 respondents (49\%) are proper, but 17 respondents $(51 \%)$ are not proper. provision pattern of supplement and breast 
Table 7. Correlation of Type of Supplement and Breastmilk with the Status of Nutrition

\begin{tabular}{llllll}
\hline \multirow{2}{*}{ Types } & Bad & $\begin{array}{l}\text { Inade } \\
\text { nutriti } \\
\text { quate } \\
\text { nutriti } \\
\text { on }\end{array}$ & $\begin{array}{l}\text { Good } \\
\text { nutrition }\end{array}$ & total & P Value \\
\hline Proper & 2 & 4 & 18 & 23 & \\
Improper & 0 & 2 & 7 & 10 & 0,204 \\
\hline Total & 2 & 6 & 25 & 33 & \\
\hline
\end{tabular}

The result of the analysis shows that $\mathrm{p}=$ 0,204 , so it can be concluded that there is no correlation between the supplement and breast milk provision pattern based on food type with nutritional status of children aged 6-24 months in the working area of Kelayan Dalam Banjarmasin.

Table 8. Correlation of the Frequency of Supplement and breast milk provision with Nutritional Status

\begin{tabular}{llllll}
\hline \multirow{5}{*}{ Frequency } & Bad & Inadequate & Good \\
& nutrition & nutrition & total & $\begin{array}{c}\mathrm{P} \\
\text { nutrition }\end{array}$ \\
& 0 & 0 & 16 & 26 & \\
\hline Proper & 0 & 6 & 9 & 17 & 0,000 \\
Improper & 2 & 6 & 25 & 33 & \\
\hline Total & 2 & 6 & & & \\
\hline
\end{tabular}

The result of analysis states that $p=0,000$, so it can be concluded that there is a relationship between the pattern of complementary feeding of milk based on the frequency with nutritional status of children aged 6-24 months in the working area of Kelayan Dalam Banjarmasin.
Table 9. Correlation Schedule of Breastfeeding and Supplement with Under five children Nutrition Status

\begin{tabular}{lllllc}
\hline \multirow{2}{*}{ Schedule } & Bad & Inadequate & Good & total & P \\
& Nutrition & Nutrition & nutrition & & Value \\
\hline Proper & 0 & 0 & 21 & 22 & \\
Improper & 2 & 6 & 4 & 11 & 0,612 \\
& & & & & \\
\hline Total & 2 & 6 & 25 & 33 & \\
\hline
\end{tabular}

The result of the analysis shows that $p=0,612$, so it can be concluded that there is no correlation between the pattern of complementary feeding based on the frequency with nutritional status of children aged 6-24 months in the working area of Kelayan Dalam Banjarmasin.

The analysis results of Breastmilk Breeding Assistance Pattern can be seen in the following table:

Table 10. Correlation of Supplement provision and

Breast milk with The Nutrition of under five children

\begin{tabular}{|c|c|c|c|c|c|}
\hline \multirow[b]{2}{*}{ Pattern } & \multicolumn{3}{|c|}{ Nutritional status } & \multirow[b]{2}{*}{ total } & \multirow{2}{*}{$\begin{array}{c}\mathrm{P} \\
\text { Value }\end{array}$} \\
\hline & $\begin{array}{l}\text { Bad } \\
\text { nutrition }\end{array}$ & $\begin{array}{l}\text { Inadequate } \\
\text { nutrition }\end{array}$ & $\begin{array}{l}\text { Good } \\
\text { Nutrition }\end{array}$ & & \\
\hline Proper & 0 & 0 & 16 & 16 & \\
\hline Improper & 2 & 6 & 9 & 17 & 0,000 \\
\hline Total & 2 & 6 & 25 & 33 & \\
\hline
\end{tabular}

The result of the analysis states that $\mathrm{p}=$ 0,000 , so it can be concluded that there is a relationship between the pattern of supplement provision and breast milk with nutritional status of children aged 6-24 months in working area of Kelayan Dalam Banjarmasin. 


\section{DISCUSSION}

Toddlers 6-24 months of age begin to be given complementary feeding of milk because at that age the toddler already has a chewing reflex with a stronger digestion. In feeding it is necessary to note the timeliness of delivery, the frequency of administration, the type of food, the amount, and the manner in which it is prepared [8]. These foods should be complementary and can meet the baby's needs. Based on the analysis of the relationship between the pattern of feeding with nutritional status of children under five years $(p=0,000 \leq 0,05)$, which means there is a relationship between supplement pattern and breast milk and the nutritional status of under-five children in the working area of Kelayan Dalam Public Health Center Banjarmasin.

This suggests that breastfeeding foods for infants aged 6-24 months are used to cover the nutritional deficiencies contained in breast milk. Thus it is quite clear that the role of supplementary food is not as a substitute for breast milk but to complement or accompany breast milk. Inadequate MP-ASI feeding is classified in the provision of MP-ASI at $<6$ months of age and proper breastfeeding is classified in children prescribed at $\geq 6$ months [9].

Based on a study by Nishani $\mathrm{H}$, et al (2015) complementary feeding after exclusive breastfeeding for 6 months can demonstrate the successful improvement of nutritional status of children aged 6-24 months in Sri Lanka [10]. Changes in mother's behavior and parenting, as well as communication and care, affect the practice of supplementary feeding in infants.

Nutrition disorders in infants and under-fives are generally due to poor quality and pattern of feeding. The pattern of giving the MP-ASI is divided into several classifications such as Type, Frequency, and Schedule. Where based on the analysis for each classification found that the frequency of complementary feeding of Breastmilk is the most influential factor on the nutritional status of children under five $(p=0,000)$, while for the type and schedule has $p>0,05$. This is in line with the recommendation by the WHO on the 10 principles of complementary feeding, where WHO says that it is necessary to increase the consistency and frequency of supplementary feeding to improve the nutritional status of under-five children. This result is also consistent with the opinion of Simondin (2007) indirect factors that affect nutritional status because with income will increase purchasing power in meeting the needs of family food [11]. In addition, there is still a poor nutritional status in this study, according to the researchers because of 
maternal disobedience to exclusive breastfeeding, too early to provide complementary foods (MP-ASI) and generally not enough energy and other nutrients. Besides, in terms of the pattern of child feeding by mothers, there are still many mother-toddlers who provide prenatal food or give the MP-ASI too early and some are too slow, and the amount and quality of nutrients MP-ASI was given is often inadequate .

This study is in line with Muchina EN (2010) study, which says that there is a relationship between the frequency of MPASI with nutritional status ( $\mathrm{p}$ value $\leq 0.05$ ) [12].

\section{CONCLUSION}

Overall, breastfeeding foods System Pattern can detect the nutritional status of children under 6-24 months in Kelayan Dalam Banjarmasin Health Center, but based on classification, only the frequency of complementary feeding of ASI related to nutritional status of children under five years old.

\section{REFERENCES}

[1] World Health Organisation (WHO). 2011. Feeding And Nutrition of Infants And Young Children. Regional Publication, European, Series 87.
[2] Kementerian Kesehatan RI. 2013. Panduan Tenaga Pelaksana Gizi. Jakarta : Kemenkes RI

[3] Medise BE, Sekartini R. 2007. Buku Pintar Bayi, Jakarta; PT Rineka Cipta;.

[4] Juwono, Lilian. 2010. Pemberian Makanan Tambahan. Jakarta : Buku Kedokteran EGC

[5] Diah, et al. 2001. Menyiapkan Makanan Pendamping ASI, Jakarta; Puspa Swara

[6] Waryana. 2010. Gizi Reproduksi. Yogyakarta : Pustaka Rihama

[7] Dinas Kesehatan Kota Banjarmasin. 2014. Laporan Status Gizi Balita Tahun 2014. Banjarmasin

[8] Gibson, RS, Ferguson EL., \& Lehrfeld, J. 2008. Complementary Foods For Infant Feeding In Developing Countries: Their Nutrient Adequacy And Improvement. European Journal of Clinical Nutrition, 72, p. 421-429

[9] Bogue, J. 2007. Parental Perceptions Of Feeding Practices In Five European Countries: An Exploratory Study. European Journal of Clinical Nutrition, 61, p. 946-956.

[10] Nishani H, et al. 2015. Nutritional Status And Associated Feeding Practices Among Children Aged 624 Months In A Selected Community In Sri Lanka. European journal of Preventive Medicine.

[11] Simondin, KB. 2007. Age At Introduction of Complementary Food And Physical Growth From 2 To 9 Months In Rural Senega. 
European Journal of Clinical

Nutrition, 51, p. 846-856

[12] Muchina EN. 2010. Relationship Between Breastfeeding Practices And Nutrional Status Of Children Aged 0-24 Months In Nairobi, Kenya Vol 10 No April 2010. AJFAND. Africa 